\title{
Konstruk Pendidikan Multikultural (Studi Urgensi Integrasi Nilai- nilai Multikultural dalam Kurikulum Pendidikan)
}

\author{
Jalwis $^{1}$, Nicolas Habibi ${ }^{2}$ \\ ${ }_{1,2}$ Institut Agama Islam Negeri (LAIN) Kerinci \\ e-mail: jalwis.stain@yahoo.com
}

\begin{abstract}
Multicultural education is an education that teaches students the values of heterogeneity in a comprehensive and thorough manner. The birth of a multicultural education discourse is a response to the symptoms of multiculturalism in Indonesian society. Therefore, the existence of multicultural education is to create stability and national integration, as well as increase the quality of society's civilization in a positive direction. There are three fundamental ideas in multicultural education, namely: (1) Equality (equality) which includes equal preference (equal dignity) and equivalent recognition/treatment (equal respect); (2) The concept of diversity that looks at the seasonings as an undisputed reality, even in one group claimed to be the same, is also a diversity; and (3) the integration in the collective framework of identities, giving and accepting, influencing each other and interaction, so that there is no recon, segregation and intercultural collisions. To prove the explanation of exposure to the data, this study used a fenomelogi approach. The research proves that the reality of multicultural education is aimed to become one of the educational alternatives that can be used as a model of education in Indonesia, because of Sunatullah multicultural society of Indonesia. All individuals in the community have equal value, degree and role in devoting and exercising their respective roles in their communities. Therefore, multicultural education should be taught to the people of Indonesia.
\end{abstract}

Keywords: multicultural education, existence, phenomenology and alternatives.

\begin{abstract}
Abstrak. Pendidikan multikultural merupakan pendidikan yang mengajarkan nilai-nilai heterogenitas kepada peserta didik secara komprehensif dan menyeluruh. Lahirnya diskursus pendidikan multikultural merupakan sebuah respon terhadap gejala multikulturalisme yang ada dalam masyarakat Indonesia. Untuk itu eksistensi pendidikan multikultural adalah menciptakan stabilitas dan integrasi nasional, serta peningkatan terhadap kualitas peradaban masyarakat ke arah yang positif. Ada tiga ide pokok dalam pendidikan multikultural, yaitu: (1) kesetaraan (equality) yang meliputi harkat keutamaan yang setara (equal dignity) dan pengakuan/perlakuan yang setara (equal respect); (2) konsep keragaman yang memandang kemajemukan sebagai realitas yang tak terbantahkan, bahkan dalam satu kelompok pun yang diklaim sama, juga terdapat keragaman; dan (3) Integrasi dalam kerangka collective identities, memberi dan menerima, saling mempengaruhi dan interaksi, sehingga tidak ada ketertutupan, segregasi dan benturan antar budaya. Untuk membuktikan penjelasan paparan data tersebut, penelitian ini menggunakan pendekatan fenomelogi. Penelitian ini membuktikan bahwa`sejatinya realitas pendidikan multikultural bertujuan untuk menjadi salah satu alternatif pendidikan yang bisa dijadikan sebagai model pendidikan di Indonesia, karena sunatullah masyarakat Indonesia yang multikultural. Semua individu dalam masyarakat memiliki kesetaraan nilai, derajat dan peran dalam mengabdikan serta menjalankan peran masing-masing dalam komunitasnya. Untuk itu, pendidikan multikultural harus diajarkan kepada masyarakat Indonesia.
\end{abstract}

Kata kunci: pendidikan multikultural, eksistensi, fenomenologi dan alternatif. 


\section{PENDAHULUAN}

Para ahli sosiologi pendidikan mengasumsikan bahwa terdapat relasi resiprokal (timbal balik) antara dunia pendidikan dengan kondisi sosial masyarakat. Relasi ini bermakna bahwa apa yang berlangsung dalam dunia pendidikan merupakan gambaran dari kondisi dalam kehidupan masyarakat. Demikian pula selanjutnya, kondisi masyarakat baik dalam, majua dalam peradaban dan sejenisnya, mencerminkan kondisi dari dunia pendidikannya. Oleh karenanya, majunya dunia pendidikan dapat menjadi cerminan majunya suatu masyarakat. Dunia pendidikan bisa menjadi salah satu indikator dari majunya masyarakat (Naim, 2010).

Dalam konteks kehidupan masyarakat yang majemuk, pendidikan menjadi salah satu media yang paling efektif untuk melahirkan generasi yang memiliki pandangan yang mampu menjadikan keberagaman sebagai bagian yang harus diapresiasikan secara konstruktif. Sebab, pendidikan bersifat sistemik, dengan tingkat penyebaran yang cukup merata. Lembaga-lembaga pendidikan dari berbagai tingkatan telah tersebar secara luas diberbagai wilayah Indonesia. Oleh karena itu, pendidikan menjadi sarana yang cukup efektif untuk mencapai tujuan ini.

Realitas hubungan resiprokal antara dunia pendidikan dengan masyarakat yang sejatinya berbanding lurus, terkadang terjadi kesenjangan. Bahkan, hubungan ini sering tidak berjalan sebagaimana yang diharapkan. Refresentasi dunia pendidikan tidak bisa digeneralisasi secara total untuk mewakili kondisi masyarakat. Demikian pun sebaliknya, implikasinya muncul kesenjangan relasi diantara keduanya. Kesenjangan ini merupakan realitas yang menjadi tantangan tersendiri bagi dunia pendidikan. Sebab masyarakat telah berkembang dalam eskalasi dan progresifitas yang tinggi, sementara dunia pendidikan sendiri masih tetap sibuk dengan beragam persoalan yang tidak mudah untuk diuraikan (Naim, 2010). Realitas pendidikan dan masyarakat mempunyai kaitan yang urgen sehingga tidak bisa dipisahkan. Ini mengasumsikan bahwa nilai-nilai pendidikan multikultural dalam konteks kehidupan masyarakat yang majemuk menjadi satu keharusan, agar masyarakat dapat hidup dengan damai dalam bingkai keberagaman. Untuk itu dalam tulisan ini penulis menguraikan berbagai term-term permasalahan tentang konstruk pendidikan multikultural.

\section{METODE}

Penelitian ini dikatagorikan jenis penelitian kualitatif dengan menggunakan metode deskriptif-analitis untuk mendeskripsi dan menganalisis data-data yang akan menjadi pembuktian dalam penelitian ini. Data-data yang berkaitan dengan penelitian ini dijelaskan secara detail sesuai dengan kegunaan dan kebutuhan penelitian. Untuk mendukung metode ini, penulis menggunakan pendekatan fenomenologi. Ini digunakan untuk membuktikan penelitian ini secara ilmiah dan 
konstruktif. Pendekatan ini juga digunakan untuk mengkaji data tentang aspek-aspek fenomena nilai multikultural dalam konteks sosial, menganalisis kesesuaian aplikatif konstruk pendidikan multikultural, serta relevansi nilai-nilai multikultural dalam kurikulum Pendidikan.

Istilah etimologi fenomenologi berasal dari kata phainein yang berarti memperlihatkan dan phainemenon yang berarti sesuatu yang muncul atau terlihat. Pendekatan fenomenologi merupakan tradisi penelitian yang menggunakan logika kualitatif yang berakar pada filosofi dan psikologi, dan berfokus pada pengalaman hidup manusia (sosiologi). Pendekatan fenomenologi menggunakan pengalaman hidup sebagai alat untuk memahami secara lebih baik tentang sosial budaya, politik atau konteks sejarah dimana pengalaman itu terjadi. Penelitian ini akan berdiskusi tentang objek kajian dengan memahami inti pengalaman dari suatu fenomena (Hadiwijono, 1992).

Penelitian ini mengkaji secara mendalam isu sentral dari struktur utama suatu objek kajian dan selalu bertanya "Apa pengalaman utama yang akan dijelaskan informan tentang subjek kajian penelitian". Peneliti memulai kajiannya dengan ide filosofis yang menggambarkan tema utama. Interpretasi dilakukan dengan melihat diskursus tentnag pendidikan multikultural, melihat bagaimana realitas dan penerapan pendidikan multikultural dan memperlihatkan fenomena serta mencari makna dari realitas fenomomena yang ada.

Peneliti dalam pendekatan fenomenologi berusaha memahami arti peristiwa dan kaitankaitannya terhadap objek yang diteliti dalam situasi-situasi tertentu. Edmund Husserl dan Alfred Schultz menjelaskan bahwa ia merupakan interpretasi terhadap pemahaman manusia. Fenomenologi tidak berasumsi bahwa peneliti mengetahui secara mutlak arti sesuatu bagi objek yang sedang diteliti. Dalam artian bahwa peneliti berusaha memahami subjek dari sudut pandang subjek itu sendiri, dengan tidak mengabaikan membuat penafsiran atau interpretasi dengan membuat skema konseptual, sampai mendapatkan makna yang berkaitan dengan pokok masalah penelitian

\section{TEMUAN}

Realitas pendidikan di Indonesia menunjukkan bahwa pendidikan multikultural belum menjadi sebuah bidang keilmuan yang berdiri sendi. Dalam artian kurikulum pendidikan multikultural belum menjadi sebuah mata pelajaran yang sudah berdiri sendiri yang sudah diajarkan pada institusi pendidikan. Dalam konteks pendidikan di Indonesia, ia hanya diajarkan dalam bagian dari sub tema dari mata pelajaran yang diajarkan oleh pendidik pada institusiinstitusi pendidikan. Keadaan ini menunjukkan bahwa ia dianggap belum menjadi bagian keilmuan yang urgen dalam pendidikan di Indonesia dewasa ini. Hal ini tentu berbanding terbalik dengan keadaan masyarakat Indnesia yang majemuk, yang berbeda ras, suku, bahasa dan agama. 
Adanya pendidikan multikultural tentu menjadi suatu keharusan. Kebutuhan akan pendidikan multikultural tentu menjadi kebutuhan yang urgen, mengingat keadaan dari masyarakat Indonesia yang beraneka ragam.

Dalam diskursus pendidikan multikultural saat ini, beberapa literatur yang terkait dengan pendidikan multikultural di Indonesia masih menjadi perdebatan oleh para ahli pendidikan. Di mana dan bagaiman posisi dari pendidikan multikultural. Apakah pendidikan multikultural sudah perlu diajarkan dan dijadikan sebagai keilmuan tersendiri (mata pelajaran yang berdiri sendiri). Sejauhmana urgensi dari pendidikan multikultural dalam menjaga kehidupan bermasyarakat yang damai, aman dan nyaman di Indonesia. Data-data ini tentu membutuhkan kajian yang lebih filosofis dan holistik, guna menjaga keutuhan Negara Kesatuan Republik Indonesia, yang salah satunya melalui pengajaran dan penanaman pendidikan multikuktural di semua instansi pendidikan di Indonesia. Temuan data-data ini juga menunjukkan bahwa urgensi konstruk pendidikan multikultural urgen untuk diterapkan dalam pendidikan di Indonesia.

\section{DISKUSI}

\section{Pendidikan Multikultural: Suatu Tinjauan Defenisi.}

Eksistensi pendidikan dalam realitas kehidupan manusia bertujuan untuk mengubah dan membentuk manusia agar mampu mengoptimalkan potensi atau kemampuan yang dimilikinya (Azra, 2005, Arief, 2004). Tujuan ini sinkron dengan arti dan konsep dari pendidikan yang dijelaskan dalam UU Sistem Pendidikan Nasional yang mendefinisikan bahwa "Pendidikan merupakan suatu usaha sadar dan terencana untuk mewujudkan suasana belajar dan proses pembelajaran, agar peserta didik secara aktif mengembangkan potensi dirinya untuk memiliki kekuatan spiritual keagamaan, pengendalian diri, kepribadian, kecerdasan, akhlak mulia, serta keterampilan yang diperlukan dirinya dan masyarakat, bangsa dan negara" (Arief A., 2009, UU Sisdiknas No. 2 Tahun 2003). Statemen ini menegaskan bahwa pendidikan adalah realitas kontinuitas kehidupan manusia. Semakin baik peradaban satu masyarakat maka akan berbanding lurus terhadap tingkat pendidikan yang ada dalam masyarakat tersebut.

Dalam KBBI, pendidikan adalah proses pengubahan sikap dan tata laku seseorang atau kelompok orang dalam usaha mendewasakan manusia melalui upaya pengajaran dan pelatihan; proses, cara, perbuatan mendidik (KBBI, 2015). Dengan kata lain, pendidikan bertujuan membimbing manusia menuju kesempurnaan sebagai seorang makhluk individu dan sosial serta makhluk spiritual. Hakikat pendidikan lebih kepada transformasi nilai-nilai budaya pembentukan kepribadian dengan segala aspeknya kepada generasi penerus (Azra, 2008; Arief A., 2004). 
Karena itu, pendidikan dapat dipahami sebagai salah satu media untuk sosialisasi nilai, pengetahuan, sikap, dan keterampilan antar generasi.

Sinkron dengan beberapa definisi sebelumnya, Azyumardi Azra juga menjelaskan bahwa pendidikan merupakan alat yang ampuh untuk melakukan perubahan (Azra, 1998). Ia menjadi kebutuhan masyarakat yang heterogen untuk hidup damai dan rukun, dalam pemberdayaan masyarakat dalam dinamika multikultural (Tilaar, Multikulturalisme: Tantangan Global Masa Depan dalam Transformasi Pendidikan Nasional, 2004). Heterogennya realitas kehidupan yang ada di masyarakat menuntut adanya pemahaman yang holistik dan komprehensif dalam menanamkan sikap dan prilaku yang baik untuk menyikapi realitas tersebut. Dalam artian, perlu adanya pendidikan multikultural di masyarakat agar terciptanya peradaban masyarakat yang selalu mengarah ke arah yang positif. Heterogenitas tersebut menjadi kekuatan bagi masyarakat dalam meningkatkan kualitas peradaban pada masanya dan untuk meningkatnya kualitas peradaban untuk generasi berikutnya.

Terminologi pendidikan multikultural dapat diartikan sebagai "Proses pengembangan seluruh potensi manusia yang menghargai pluralitas dan heterogenitas sebagai konsekuensi keragaman budaya, etnis, suku dan aliran (agama) (Maslikhah, 2007)". Bikhu Parekh dalam bukunya Retbinking Multiculturalisme: Cultural Diversity and Political Theory mendefinisikan bahwa pendidikan multikultur adalah an education in freedom, both in the sense of freedom from ethnocentric prejudices and biases, and freedom to eksplore and learn from other cultures and respectives" (Parekh, 2000). Hal yang sama juga dijelaskan oleh Prudance Crandall dalam kutipan Ainnurrofik Dawam dalam bukunya Emoh Sekolah Menolak. Komersialisasi Pendidikan dan Kanibalisme Intelektual Menuju Pendidikan Multikultural, menjelaskan bahwa pendidikan multikultural adalah pendidikan yang memperhatikan secara sungguh-sungguh terhadap latarbelakang peserta didik baik dari aspek keragaman suku (etnis), ras, agama (aliran kepercayaan) dan budaya (kultur) (Dawam, 2003).

Pernyataan ini menegaskan bahwa pendidikan multikultural adalah pendidikan yang mengajarkan nilai-nilai heterogenitas kepada peserta didik secara komprehensif dan menyeluruh. Semua aspek menjadi pertimbangan dalam proses pendidikan yang berlangsung. Dalam artian semua peserta didik dididik tanpa membedakan latar agama, sosial, budaya dan ekonomi mereka dan semuanya diperlakukan sama.

Jalwis dalam disertasinya 'Konsep Pendidikan Multikultural dalam al-Qur'an dan Relevansinya dengan Pendidikan Multikultural dalam Pembelajaran Pendidikan Agmam Islam di SMA Kota Sungai Penuh” juga menjelaskan bahwa dalam al-Qur'an pun juga memebenarkan realitas multikultural. Multikultural dalam perspektif al-Qur'an merupakan sebuah realitas aturan Tuhan yang qat'i, dan tidak mungkin diingkari. Setiap orang akan menghadapi kemajemukan 
dimanapun dan dalam keadaan apapun. Ungkapan ini menggambarkan bahwa Islam menghargai multikultural, karena Islam menghargai perbedaan individu untuk hidup bersama dan saling menghormati satu dengan yang lain. Islam merupakan agama yang universal, yang menjunjung tinggi nilai-nilai kemanusiaan, persamaan hak dan mengakui adanya keberagaman latar budaya dan kemajemukan. Adanya pendidikan multikultural tentu memberikan dampak yang positif terhadap sunatullah masyarkat Indonesia yang majemuk. Pengajaran akan nilai-nilai multikultural, harus mampu merubah level kelas serta menumbuhkan rasa dan suasana kebersamaan yang penuh dengan toleransi (Jalwis, 2018).

Berbanding lurus dengan statemen ini, H.A.R. Tilaar juga menjelaskan bahwa konsep dasar pendidikan multikultural merupakan suatu wacana lintas batas. Dalam pendidikan multikultural diajarkan keadilan sosial, demokrasi, dan hak asasi manusia. Karena itu, pendidikan multikultural juga berkaitan dengan isu-isu politik, sosial, kultural, moral, edukasional, dan agama. Kajian ini dibutuhkan untuk memperoleh pengertian dan pemahaman akan pendidikan multikultural secara holistik (Tilaar, 2003).

Lebih lanjut dalam pemetaannya, definisi pendidikan multikultural sesungguhnya dapat dilihat dari tiga sisi, yaitu: sebagai sebuah ide atau konsep, sebagai gerakan pembaruan pendidikan, dan sebagai sebuah proses (Khaerudin, http://www.ilmupendidikan.net/?=8). Banks, dalam kutipan Azyumardi Azra mendefinisikan pendidikan multikultural sebagai bidang kajian dan disiplin yang muncul yang tujuan utamanya untuk menciptakan kesempatan pendidikan yang setara bagi peserta didik meskipun berasal dari ras, etnik, kelas sosial, dan kelompok budaya yang berbeda (Azra, 2004).

Dari penjelasan-penjelasan sebelumnya, maka penulis berkesimpulan bahwa pendidikan multikultural adalah sebuah ide (gagasan), gerakan dan proses pengembangan potensi, sikap dan tata laku manusia dalam usaha memperoleh pengetahuan, sikap dan ketrampilan yang diperlukan dalam menjalankan peran-peran merka seefektif mungkin pada masyarakat demokrasi-pluralistik serta diperlukan untuk berinteraksi, negosiasi, dan komunikasi dengan warga dari kelompok beragam. agar tercipta sebuah tatanan masyarakat bermoral yang berjalan untuk kebaikan bersama.

\section{Prinsip-prinsip Dasar Pendidikan Multikultural}

Realitas dinamika lahirnya pendidikan multikultural merupakan sebuah respon terhadap gejala multikulturalisme yang ada dalam masyarakat. Lahirnya Pendidikan multikultural bertujuan untuk menciptakan stabilitas dan integrasi nasional, serta peningkatan terhadap kualitas peradaban masyarakat ke arah yang positif. Karena itu, latarbelakang kehidupan masyarakat harus mendapatkan perhatian yang proporsional, sehingga model pendidikan yang diberikan kepada 
mereka sesuai dengan situasi dan kondisi masyarakat (Maslikhah, 2007). Pendidikan multikultural berkehendak pada penghormatan dan penghargaan setinggi-tingginya terhadap harkat dan martabat manusia tanpa melihat perbedaan yang ada. Karena itu, dalam perspektif pendidikan multikulturalisme ada tiga ide pokok yang dasar pemikiran, yaitu:

1) Kesetaraan (equality) yang meliputi harkat keutamaan yang setara (equal dignity) dan pengakuan/perlakuan yang setara (equal respect).

2) Konsep keragaman yang memandang kemajemukan sebagai realitas yang tak terbantahkan, bahkan dalam satu kelompok pun yang diklaim sama, juga terdapat keragaman.

3) Integrasi dalam kerangka collective identities, memberi dan menerima, saling mempengaruhi dan interaksi, sehingga tidak ada ketertutupan, segregasi dan benturan antar budaya. Dalam konteks keberagamaan, integrasi bisa dilakukan melalui peneguhan fungsi sosial agama: fungsi menegakkan keadilan, kesejahteraan, keharmonisan bersama, ta'aruf dan ta'awun, serta melalui keberagamaan inklusif (Masngud, 2010).

Dalam konteks prinsip dasar pendidikan multikultural, ia bukanlah doktrin politik pragmatik, melainkan sebagai cara pandang kehidupan manusia. Keanekaragaman merupakan suatu yang tidak bisa dihindari siapun. Ini berarti bahwa perbedaan menjadi realitas fenomena dari kehidupan yang tidak bisa dihindari (Rosyada, 2010). Lebih lanjut, Dede Rosyada menjelaskan bahwa pendidikan multikultural meliputi:

1) Tentang hak-hak individual dan hak-hak kolektif dari setiap warga negara masyarakat, seperti: hak setiap individu dari suatu bangsa yang memiliki hak yang sama untuk mendapatkan hakhak asasi kemanusiaannya.

2) Kebiasaan individual dan budaya, yakni bahwa setiap individu termasuk etnik minoritas memiliki kebebasan untuk berkreasi, berkarya bahkan untuk mengembangkan dan memajukan budayanya.

3) Keadilan dan hak-hak minoritas, yakni seluruh anggota masyarakat memiliki hak yang sama untuk memperoleh keadilan dari negara, dan bahkan mereka juga memiliki hak untuk mengembangkan kultur etniknya, termasuk etnik minoritas yang harus mampu mengelola bahasa, dan berbagai institusi sosialnya, agar tidak hilang dalam budaya kelompok etnik mayoritas.

4) Jaminan minoritas untuk bisa berbicara dan keterwakilan aspirasinya dalam struktur pemerintahan legislatif.

5) Toleransi dan batas-batasnya, yakni bahwa etnik minoritas yang tidak terwakili langsung di parlemen atau birokrasi, harus dilindungi oleh etnik atau kelompok yang menguasai lembagalembaga otoritatif untuk pengambilan kebijakan-kebijakan publik (Rosyada, 2010). 
Realitas prinsip dasar pendidikan multikultural ini menghadirkan paradigma baru bahwa cara pandang ini harus ditanamkan dalam setiap individu. Ini bertujuan agar terciptanya suasana yang kondusif di semua sisi kehidupan masyarakat, karena heterogenitas adalah sunatullab yang tidak bisa dihindari oleh siapa pun. Bahkan, penerapan prinsip-prinsip dasar pendidikan multikultural bisa menjadi salah satu solusi untuk menjaga kedamaian dan ketentraman kehidupan berbangsa dan bernegara. Heterogenitas kehidupan masyarakat, bisa menjadi nilai positif dalam meningkatkan kualitas kehidupan dan peradaban, jika setiap individu dapat memahami tentang pendidikan multikultural secara konstruktif, filosofis dan holistik.

Gollnick dalam Multikultural Education in a Pluralistic Sociaty menjelaskan ada tujuh unsur yang mendasari prinsip-prinsip multikultural yaitu; kelas sosial, etnik, gender, agama, bahasa, umur dan pendidikan. Lebih lanjut Gollnick menjelaskan bahwa konsep tentang multikultural education berdasarkan atas keyakinan dan asumsi sebagai berikut; pertama, pebedaan budaya menjadi kekuatan dan nilai; kedua, instansi (sekolah) harus dibentuk untuk mengekspresikan makna hak asasi manusia dan menghormati hak asasi manusia; ketiga, keadilan sosial dan persamaan hak bagi seluruh masyarakat harus menjadi puncak kepentingan dalam mendesain dan melaksanakan kurikulum; keempat, sikap dan nilai-nilai penting yang dapat membentuk masyarakat yang demokratis, perlu untuk dipromosikan di sekolah; kelima, para pendidik seharusnya bekerjasama dengan keluarga dan masyarakat untuk menciptakan lingkungan yang mendukung multikulturalisme (Donna, 2002). Instansi (sekolah) menjadi salah satu bagian yang urgen dalam menanam dan menginternalisasikan nilai-nilai multikultural dalam setiap individu.

Jalwis (Jalwis, 2018) menegaskan bahwa prinsip-prinsip nilai multikultural harus diterapkan dalam beberapa materi mata pelajaran di sekolah. Pengajaran akan nilai-nilai multikultural, diintegrasikan dalam mata pelajaran pendidikan agama yang bersifat transformatif. Ia bisa diajarkan dengan berbagai metode, serta senantiasa bersifat reflektif, memadukan materi pembelajaran dengan kondisi latar belakang siswa. Lebih lanjut ia menjelaskan bahwa pembelajaran pendidikan multikultural juga mempunyai relevansi dengan apa yang terdapat dalam al-Qur'an, karena PAI sumber utamanya adalah al-Qur'an dan Hadis. Bahkan, al-Qur'an dan hadis menjadi sumber penyusunan rencana pembelajaran agama di sekolah.

Menurut Parekh, implikasinya terhadap pengembangan pendidikan multikultural adalah pemasukan bahan ajar yang berisi ide dari berbagai kelompok budaya. Diperlukan adanya pendidikan yang leluasa untuk mengeksplorasi perspektif dan budaya orang lain. Dengan mengekplorasi itu akan diperoleh inspirasi sehingga membuat anak menjadi sensitif terhadap pluralitas cara hidup, cara yang berbeda dalam menganalisa pengalaman dan ide, dan cara melihat berbagai temuan sejarah yang ada di seluruh dunia. Pendidikan memang mengajarkan nilai-nilai 
budayanya sendiri namun selain itu juga perspektif dan budaya orang lain di wilayah lain di seluruh dunia. Hal ini dapat membuat siswa "melek budaya" (cultural literacy) yang mampu melihat berbagai sudut pandang budaya yang pernah hidup di berbagai belahan dunia. Menurut Babtiste, Perlu adanya pelembagaan filsafat pluralisme budaya dalam sistem pendidikan yang dilandasi prinsip persamaan, saling menghormati, penerimaan dan pemahaman, dan komitmen moral demi keadilan sosial. Pendidikan Multikultural selalu dilandasi prinsip persamaan dan keadilan sosial. Implikasinya, kurikulum perlu direformasi sehingga benar-benar mencerminkan penghormatan atas pluralitas budaya. Agar pendidikan lebih multikultural, maka pendidikan dan pengajaran harus memperkokoh pluralisme dan menentang adanya rasisme, diskriminasi gender dan bentukbentuk lain dari intoleransi dan dominasi sosial. Pada konteks ini, harus lakukan transformasi kurikulum, model pembelajaran, suasana sekolah, kegiatan ekstrakurikuler dan peran guru sebagai multikultural.

Pendidikan multikultural sekurang-kurangnya mempunyai lima tujuan. Pertama, meningkatkan pemahaman diri dan konsep diri secara baik. Kedua, meningkatkan kepekaan dalam memahami orang lain, termasuk terhadap berbagai kelompok budaya di negara sendiri dan negara lain. Ketiga, meningkatkan kemampuan untuk merasakan dan memahami kemajemukan, interpretasi kebangsaan dan budaya yang kadang-kadang bertentangan menyangkut sebuah peristiwa, nilai dan perilaku. Keempat, membuka pikiran ketika merespon isu. Kelima, memahami latar belakang munculya pandangan klis atau kuno, menjauhi pandangan stereotipe dan mau menghargai semua orang. Untuk itu, dalam implementasinya paradigma pendidikan multikultural dituntut untuk berpegang pada prinsip-prinsip berikut ini:

1. Pendidikan multikultural harus menawarkan beragam kurikulum yang merepresentasikan pandangan dan perspektif banyak orang.

2. Pendidikan multikultural harus didasarkan pada asumsi bahwa tidak ada penafsiran tunggal terhadap kebenaran sejarah.

3. Kurikulum dicapai ssuai dengan penekanan analisis komparatif dengan sudut pandang kebudayaan yang berbeda-beda.

4. Pendidikan multikultural harus mendukung prinsip-prinsip pokok dalam memberantas pandangan klis tentang ras, budaya dan agama.

Prinsip-prinsip penting dalam penerapan pendidikan multikultural adalah kurikulum berdasarkan sejarah dan berpusat pada keragaman, berorientasi pada perbaikan, pengajaran mengarah pada keragaman, kurikulum tergantung pada konteks, bersifat menyerap keragaman dan dapat diterapkan secara luas, bersifat komprehensif serta mencakup semua level pendidikan. 
Untuk merekonstruksi konsep pendidikan multikultural, Tilaar dalam kutipan M. Gollnick Donna dan Philip C. Chin tentang Multikultural Education in a Pluralistic Sociaty ditegaskan tiga lapis diskursus yang berkaitan yaitu:

1. Masalah kebudayaan. Dalam hal ini terkait masalah-masalah mengenai identitas budaya suatu kelompok masyarakat atau suku. Bagaimanakah hubungan antara kebudayaan dengan kekuasaan dalam masyarakat. Apakah kelompok-kelompok dalam masyarakat mempunyai kedudukan dan hak yang sama dalam kesempatan mengekspresikan identitasnya di masyarakat luas.

2. Kebiasaan-kebiasaan, tradisi dan pola-pola kelakuan yang hidup di dalam suatu masyarakat

3. Kegiatan atau kemajuan tertentu (acbivement) dari kelompok-kelompok dalam masyarakat yang merupakan identitas yang melekat pada kelompok tersebut (Donna, 2002).

Paparan data-data menunjukkan bahwa ide dari pendidikan multikultural semestinya bisa diterapkan. Heterogenitas masyarakat Indonesia menuntu adanya pendidikan multikultural. Ia perlu diterapkan untuk menghindari konflik perpecahan dan menjaga stabilitas masyarakat Indonesia.

\section{Urgensi Pendidikan Multikultural}

Transformasi dan pembaharuan dalam pendidikan merupakan suatu keharusan, karena ia berfungsi sebagai salah satu jawaban dan solusi dari permasalahan yang semakin dinamis dan komplek fenomena pendidikan dan masyarakat (Langgulung, 1986; Purwanto, 2000). Pendidikan tidak dapat dipisahkan dari perubahan realitas sosial yang dipengaruhi oleh kebudayaan yang multikultural dalam masyarakatnya (Naim, 2010). Ini menegaskan bahwa karakter peserta didik lahir dari perilaku umum yang dilakukan secara kolektif komunal, diajarkan melalui contoh dan prilaku, disimulasikan secara edukatif, dan membentuk karakter peserta didik.

Pendidikan multikultural sebagai pendidikan alternatif patut dikembangkan dan dijadikan sebagai model pendidikan di Indonesia dengan alasan:

1. Realitas bahwa Indonesia adalah negara yang dihuni oleh berbagai suku, bangsa, etnis, agama, dengan bahasa yang beragam dan membawa budaya yang heterogen serta tradisi dan peradaban yang beraneka ragam.

2. Pluralitas tersebut secara inheren sudah ada sejak bangsa indonesia ada.

3. Masyarakat menentang pendidikan yang berorientasi bisnis, komersialisasi dan kapitalis yang mengutamakan golongan atau orang tertentu.

4. Masyarakat tidak menghendaki kekerasan dan kesewenang-wenangan pelaksanaan hak setiap orang. 
5. Pendidikan multikultur sebagai resistensi fanatisme yang mengarah pada berbagai jenis kekerasn dan kesewenang-wenangan.

6. Pendidikan multikultural memberikan harapan dalam mengatasi berbagai gejolak masyarakat yang terjadi akhir-akhir ini.

7. Pendidikan multikultural sarat dengan nilai-nilai kemanusiaan, sosial, kealaman, dan ketuhanan (Maslikhah, 2007).

Ide pendidikan multikultural tentu memberi spirit bagi lembaga pendidikan nasional untuk menanamkan sikap kepada peserta didik, agar menghargai budaya, agama dan keyakinan orang lain. Dengan harapan, pendidikan multikultural akan membantu siswa mengerti menerima dan menghargai orang lain yang berbeda suku, budaya, nilai dan kepribadian. Karena itu, pendidikan multikultural yang dimaksud adalah sebuah sistem pendidikan yang berupaya untuk meredam kesenjangan sosial, kelas sosial, kecemburuan sosial dengan mengenalkan serta mensosialisasikan nilai-nilai kebersamaan dan inklusiv (Zubaedi, 2004).

Hakikat manusia (peserta didik) dalam konteks pendidikan multikultural menjadi sangat signifikan karena beberapa hal:

1. Pendidikan multikultural memandang bahwa manusia memiliki beberapa dimensi yang harus diakomodir dan dikembangkan secara keseluruhan. Orientasi pendidikan multikultural adalah untuk"memanusiakan manusia". Di sini dapat dijelaskan lebih jauh bahwa kemanusiaan manusia pada dasarnnya adalah pengakuan akan pluralitas.

2. Pendidikan multikultural tidak mentolerir adanya ketimpangan kurikulum. Pendidikan multikultural mengakui dan menghargai adanya perbedaan filosofi keilmuan. Karena sesuai dengan dimensi manusia yang sangat beragam tersebut, seseorang akan mengembangkan dirinya sesuai dengan bakat dan minatnya. Oleh karena itu sangatlah tidak relevan ketika pendidikan multikultural hanya mengembangkan kualitas kognisi intelektual belaka.

3. Pendidikan multikultural hanya berupaya menjadi jembatan emas bagi keterpisahan lembaga pendidikan dari kemanusiaan masyarakat. Hal ini didasarkan pada asumsi bahwa pendidikan multikultural senantiasa mengakomodir semua keinginan dan kebutuhan semua masyarakat. Artinya, pendidikan multikultural tidak boleh membedakan kebutuhan yang bersifat intelektual, spiritual, material, emosional, etika, estetika, sosial, ekonomikal, dan transendental dari seluruh lapisan msayarakat dengan berbagai ragam stratanya. Dengan demikian lembaga pendidikan tidak akan terlepas dari wilayah lokalnya.

4. Pendidikan multikultural menghendaki biaya pendidikan menjadi sangat ringan dan dapat digapai oleh seluruh lapisan masyarakat. 
A. Effendi Sanusi mengatakan bahwa Pendidikan multikultural sebagai wacana baru di Indonesia dapat diimplementasikan tidak hanya melalui pendidikan formal, bahkan juga dapat dimplementasikan melalui pendidikan non-formal. Dalam pendidikan formal, pendidikan multikultural tidak harus dirancang khusus sebagai muatan substansi tersendiri, tetapi dapat diintegrasikan dalam kurikulum yang sudah ada melalui bahan ajar atau model pembelajaran. Di perguruan tinggi misalnya, dari segi substansi, pendidikan multikultural dapat diintegrasikan misalnya melalui mata kuliah umum, seperti kewarganegaraan, agama, dan bahasa. Pada tingkat SD, SLTP, SLTA, pendidikan multikultural dapat diintegrasikan dalam bahan ajar seperti agama, sosiologi, antropologi dan bahkan menjadi matapelajaran (bidang keilmuan) yang berdiri sendiri. Dalam aplikasinya, ia dapat diterapkan melalui model pembelajaran, seperti diskusi kelompok atau kegiatan ekstrakurikuler. Dalam pendidikan nonformal, pendidikan multikultural dapat disosialisasikan melalui pelatihan-pelatihan dengan model pembelajaran yang responsif multikultural dengan mengedepankan penghormatan terhadap perbedaan, baik ras, suku, maupun agama antar anggota masyarakat.

Dalam konteks Indonesia yang ber-"Bhinneka Tungga Ika", dalam arti berbeda suku, agama, dan budaya, pendidikan dengan latar yang multikultural perlu dirancang-ulang dan dikemas kembali dalam wadah yang lebih komprehensif dan lebih bermakna. Pendidikan multikultural perlu direformulasikan dan dioperasionalisasikan dalam rangka mewujudkan masyarakat yang harmonis, inklusif dan saling menghargai. Untuk itu, dirasakan perlunya membangun paradigma baru dalam pendidikan multikultural yang sesuai dengan konteks Indonesia dengan semboyan Bhineka Tunggal Ika, dengan nilai-nilai agama dan Pancasila sebagai sumber nilai dan rujukan utamanya.

Realitas semboyan Bhineka Tunggal Ika dalam masyarakat Indonesia menunjukkan bahwa masyarakat Indonesia merupakan masyarakat yang multikultural. Masyarakat multikultural merupakan masyarakat yang mampu memerankan dirinya sebagai penengah bagi proses rekonsiliasi dialektika. Ia menawarkan kesadaran multikulturalisme, yang dibangkitkan melalui pendidikan multikultural di sekolah-sekolah (Masrawai, 2007). Dengan demikian, jelas bahwa orientasi dari pendidikan multikultural adalah pada proses penyadaran yang berwawasan pluralis sekaligus berwawasan multikultural. Pendidikan semacam ini harus dilihat sebagai bagian dari upaya komperhensif mencegah dan menanggulangi konflik etnis agama, radikalisme agama, sparatisme, dan disintegrasi bangsa, sedangkan nilai dasar dari konsep pendidikan ini adalah toleransi.

Pendidikan multikultural dalam konteks ini juga diartikan sebagai proses pendidikan yang memberikan peluang yang sama pada seluruh anak bangsa tanpa membedakan perlakuan karena 
perbedaan etnik, budaya dan agama yang memberikan penghargaan terhadap keragaman, dan yang memberikan hak-hak yang sama bagi etnik minoritas dalam upaya memperkuat persatuan dan kesatuan, identitas nasional dan citra bangsa di mata dunia internasional. Pendidikan multikultural adalah salah satu solusi dari banyaknya konflik dan ketegangan-ketegangan bermotif SARA yang kerap muncul di Indonesia yang menguras energi bangsa ini.

Paparan data-data ini menegaskan bahwa pendidikan dan agama urgen dalam realitas sosial masyarakat yang multikultural. Pendidikan dan agama menjadi counter dalam menjaga harmonisasi (insaniyyah) dalam suatu komunitas. Prinsip dasar pendidikan adalah usaha sadar dan terencana mewujudkan suasana belajar dan proses pembelajaran, agar peserta didik secara aktif mengembangkan potensi dirinya untuk memiliki kekuatan spiritual keagamaan, pengendalian diri, kepribadian, kecerdasan, akhlak mulia, serta keterampilan yang diperlukan dirinya, masyarakat, bangsa dan negara (Langgulung, 1986; Ahmad, 1989).

Dalam konteks keislaman, Islam sebagai suatu perangkat ajaran dan nilai, meletakkan konsep dan doktrin yang merupakan rahmat li al-alamin. Sebagai ajaranyang memuat nilai-nilai normatif, maka Islam sarat dengan ajaran yang menghargai dimensi pluralis-multikultural. Begitu bagus dan indahnya Islam dalam memandang dan menempatkan martabat dan harkat manusia, baik sebagai makhluk individu maupun sebagai anggota sosial. Dalam al-Qur'an dijelaskan tentang kewajiban seorang muslim untuk menjadi juru damai, yaitu senantiasa menjaga kedamaiandan kerukunan hidup dalam lingkungannya. Sebagaimana firman Allah yang artinya "Tidak ada kebaikan pada kebanyakan bisikan-bisikan mereka, kecuali menyurub (manusia) memberi sedekah, berbuat ma'ruf (baik), atau melakukan islah (perdamaian) di antara manusia". Kewajiban ini tidak banya ditujukan kepada saudara seagama saja, sebab Allab SWT, secara tegas menyatakan bahwa manusia berasal dari seorang laki-laki (Adam) dan seorang perempuan (Hawa), sehingga mereka semua bersaudara. (Q.S. Al-Nisa: 114)

Lebih jauh, ajaran Islam juga mewajibkan umatnya mencegah segala bentuk penganiayaan yang hendak dilakukan oleh "saudaranya" kepada "saudaranya” yang lain. Sebagaimana termaktub dalam hadits Rasul: "Tolonglab saudaramu, baik ia berlaku aniaya maupun teraiaya. Seorang sahabat bertanya, wahai Rasulullah, kami pasti akan menolongnya jika ia teraniaya, akan tetapi bagaimana kami menolongnya jika ia berlaku aniaya?, Nabi menjawab: Halangi dan cegablab dia agar tidak berbuat aniaya. Yang demikian itulah pertolongan baginya”. (HR.Bukhori).

Ini menegaskan bahwa Islam dan urgensi dari pendidikan multikultural berjalan beriringan dalam mencapai nilai-nilai yang positif bagi masyarakat. Dalam artian, tentu pengajaran pendidikan agama Islam dalam konteks pendidikan multikultural menjadi maksud dari prinsip dasar pendidikan yang dimaksudkan. Bank menjelaskan pendidikan multikultural adalah 
pendidikan untuk kebebasan, yaitu untuk membantu para siswa dalam mengembangkan pengetahuan, sikap dan keterampilan dalam berpartisipasi dalam masyarakat yang bebeas dan demokratis. Eksistensi pendidikan multikultural harus mampu mengembangkan kebebasan, kemampuan dan ketrampilan dalam menerobos batas-batas budaya, etnis dalam berpartisipasi dengan kebudayaan dan kelompok lain. Substansi Pendidikan multikultural diharapkan mampu menjadikan pendidikan untuk kebebasan (as "education for freedom") dan penyebarluasan inklusif dalam rangka mempererat hubungan antar sesame (as "includive and cementing movemen"). Karena itu, pendidikan multikultural perlu diadopsi dan diakomodir untuk kebutuhan pendidikan Indonesia kontemporer, dikarenakan ia menyangkut keragaman bangsa yang sudah tidak asing bagi masyarakat. Inilah kekayaan yang luar biasa. Kemajemukan yang menjadi landscape dan panorama Nusantara yang tak akan pernah habis untuk digali, harus mampu menjadi potensi yang sejatinya terus ditingkatkan. Dinamika perkembangan global yang membawa perubahan-perubahan dalam kosntelasi sosio-politik, ekonomi, kultural dan pendidikan, tentu membutuhkan pendidikan tentang realitas multikultural masyarakat Nusantara yang sudah nenjadi sunatullah dari Yang Maha Esa. Pada akhirnya, pendidikan Multikultural dapat dipahami sebagai sebuah paradigma tentang pendidikan tentang kesetaraan semua ekspresi budaya serta pendidikan tentang realitas perbedaan dalam masyarakat. Adanya perbedaan dalam masyarakat menjadi realitas sunatullah yang harus diterima oleh semua anggota masyarakat. Semua masyarakat memilki kesetaraan nilai, derajat dan peran dalam mengabdikan serta menjalankan peran masing-masing dalam komunitasnya.

\section{REFERENSI}

Ahmad, D. M. (1989). Pengantar Filsafat Pendidikan Islam. Bandung: Al-Ma'arif.

Arief, A. (2009). Membumikan NIlai-nilai Islam dalam Masyarakat Majemuk. Jakarta: Suara ADI. . (2009). Membumikan NIlai-nilai Islam dalam Masyarakat Majemuk. Jakarta: Suara ADI.

. (2004). Sejarah Pertumbuban dan Perkembangan Lembaga Pendidikan Islam Klasik. Bandung: Angkasa.

Azra, A. (2004). Dari Pendidikan Kewargaan hingga Pendidikan Multkultural : Pengalaman Indonesia. Edukasi: Jurnal Penelitian Pendidikan Agama dan Keagamaan, 19-20.

(1998). Esai-esai Intelektual Muslim dan Pendidikan Islam. Jakarta: Logos Wacana Ilmu.

. (2008). Pendidikan Islam Tradisi dan Modernisasi di Tengah Tantangan Milenium III. Jakarta: Prenada. 
Dawam, a. (2003). Emoh Sekolah Menolak Komersialisasi Pendidikan dan Kanibalisme Intelektual Menuju Pendidikan Multikultural. Yogyakarta: INspeal Ahimsa KArya.

Donna, M. G. (2002). Multikultural Education in a Pluralistic Sociaty. New Jersey: Pearson Education Inc.

Hadiwijono, H. (1992). Sari Sejarah FIlsafat 2. Yogyakarta: Kanisius.

Jalwis. (2018). Konsep Pendidikan Multikultural dalam al-Qur'an dan Relevansinya dengan Pendidikan Multikultural dalam Pembelajaran Pendidikan Agmam Islam di SMA Kota Sungai Penuh. Disertasi PPs UIN Imam Bonjol Padang, 209-210.

Langgulung, H. (1986). Manusia dan Pendidikan Suatu Analisa Psikologi dan Pendidikan. Jakarta: Pustaka al-Husna.

Maslikhah. (2007). Pendidikan Multikultural: Rekonstruksi Sistem Pendidikan Berbasis Kebangsaan. Surabaya: STAIN Sala Tiga Press.

Masngud, d. (2010). Pendidikan Multikultural. Yogyakarta: Idea Press.

Masrawai, Z. (2007). Al-Quran Kitab Toleran: Inklusivisme, Pluralisme dan Multikultural. Jakarta: Penerbit Fitrah.

Naim, N. d. (2010). Pendidikan Multikultural: Konsep dan Aplikasi. Yogyakarta: Pustaka Pelajar.

Parekh, B. (2000). Rethinking Multikulturalisme: Cultural Diversity and Political Theory. Cambridge: Harvard University Press.

Purwanto, N. (2000). Ilmu Pendidikan Teoritis dan Praktis. Bandung: Remaja Rosda KArya.

Tilaar, H. (2003). Kekuasaan dan Pendidikan. Magelang: Indinesia Tera.

Tilaar, H. (2004). Multikulturalisme: Tantangan Global Masa Depan dalam Transformasi Pendidikan Nasional. Jakarta: Grasindo.

Zubaedi. (2004). Telaah Konsep Multikulturalis medan Implementasinyadalam Dunia Pendidikan. Hermenia , 1-2. 